\title{
PENDOKUMENTASIAN STANDAR ASUHAN KEPERAWATAN DI RUMAH SAKIT UMUM DAERAH MAMUJU, INDONESIA
}

\author{
Supratti $^{1}$, Ashriady $^{2}$ \\ ${ }^{1}$ Jurusan Keperawatan Poltekkes Kemenkes Mamuju, \\ ${ }^{2}$ Jurusan Kebidanan Poltekkes Kemenkes Mamuju
}

\begin{abstract}
Services in Regional Hospital of Mamuju generally still complained of patients and their families in all treatments. The aim of research to determine the standard of nursing care documentation in Regioanal Hospital of Mamuju. This type of research is descriptive quantitative research with observational approach. This study was conducted in March to Okober 2015 in Regional Hospital of Mamuju. Subjects in this research is all nurses who perform nursing documentation with a number of research subjects as many as 93 people. Variables studied nursing assessment, diagnosis, planning, implementation and evaluation using a standard observation sheet nursing care, used univariate data analysis. The results showed nursing documentation based on the standard of nursing care which is less complete assessment category 91 nurses $(97.8 \%)$, nursing diagnoses relevant category 47 nurses $(50.5 \%)$, planning the relevant category 44 nurses $(47.3 \%)$, the implementation of category complete 49 nurses $(52.7 \%)$ and the evaluation of the complete category 59 nurses $(63.4 \%)$.
\end{abstract}

Keyword: nursing documentation, nursing care.

\section{PENDAHULUAN}

Adanya kesepakatan pasar bebas ASEAN (AFTA) tahun 2003 dan disusul dengan AFEC tahun 2010 untuk Asia Pasifik dan 2020 untuk sedunia, serta UU No. 38 tahun 2014 tentang Keperawatan dan Peraturan Menteri Kesehatan No. 17 tahun 2013 tentang izin dan penyelenggaraan Praktik Perawat sebagai mayoritas pemberi layanan di Rumah Sakit semakin berat, karena harus mampu berkompetisi dalam mutu asuhan keperawatan sesuai dengan standar global.

Seiring dengan Keputusan Menteri Kesehatan Republik Indonesia 836/MENKES/SK/2005, tentang Pedoman Pengembangan Kinerja ini dapat diterapkan diseluruh sarana pelayanan kesehatan khususnya Rumah Sakit dan Puskesmas di Indonesia, sehingga mempercepat pencapaian indikator standar pelayanan minimal kota dan pencapaian pelayanan kesehatan yang bermutu yang akhirnya akan terwujud Indonesia sehat 2025. Perawat sebagai suatu profesi dapat mempertahankan dan meningkatkan mutu asuhan keperawatan maka jawabannya adalah dengan adanya standar. Standar merupakan level kinerja yang diinginkan dan yang dapat dicapai dimana kerja aktual dapat dibandingkan (Nursalam, 2011).

Standar merupakan level kinerja yang diinginkan dan yang dapat dicapai dimana kerja aktual dapat dibandingkan. la memberikan petunjuk kinerja mana yang tidak cocok atau tidak dapat diterima. Standar praktek keperawatan adalah pernyataan tentang apa yang dibutuhkan oleh registered nurse untuk dijalankan sebagai professional keperawatan. Secara umum, standar ini mencerminkan nilai profesi keperawatan dan memperjelas apa yang diharapkan profesi keperawatan dari pada anggotanya.

Pasien dan keluarga pasien masih ada yang mengeluhkan pelayanan di setiap perawatan RSUD kabupaten Mamuju. Berdasarkan fenomena ini, penulis tertarik meneliti pendokumentasian keperawatan berdasarkan standar asuhan keperawatan di RSUD Kabupaten Mamuju. Tujuan penelitian ini untuk mengetahui pendokumentasian keperawatan berdasarkan standar asuhan keperawatan di RSUD Kabupaten Mamuju.

\section{BAHAN DAN METODE Desain Penelitian}

Jenis penelitian ini adalah penelitian kuantitatif deskriptif dengan pendekatan observasional.

\section{Lokasi dan Waktu Penelitian \\ Penelitian ini dilaksanakan di ruang VIP, perawatan bedah, penyakit dalam (interna), perawatan anak, dan NICU (Neonate Intensive Care Unit) Rumah Sakit Umum Daerah}


Kabupaten Mamuju Sulawesi Barat pada bulan Maret sampai Oktober 2015.

\section{Subyek Penelitian}

Subyek penelitian seluruh perawat yang melakukan pendokumentasian, sebanyak 93 perawat.

\section{Instrumen Penelitian}

Instrumen yang digunakan adalah lembar observasi dengan menggunakan skala ordinal: kelengkapan (kurang lengkap, cukup lengkap, lengkap), keakuratan dan nyata (kurang akurat, cukup akurat, akurat dan nyata), relevansi (kurang relevan, cukup relevan, relevan) dan menganalisa pendokumentasian keperawatan berdasarkan pengkajian, diagnosa, perencanaan, implementasi dan evaluasi.

\section{HASIL PENELITIAN \\ Karakteristik Responden}

Hasil penelitian ini menunjukkan bahwa sebagian besar responden adalah Perempuan yaitu 85 perawat $(91,4 \%)$. Responden yang memiliki status pernikahan kawin sebanyak 50 perawat $(53,8 \%)$. Pendidikan responden terbanyak pada pendidikan DIII Keperawatan yaitu 59 perawat $(63,4 \%)$, sebagian besar responden memiliki status kepegawaian kontrak yaitu 47 perawat $(50,5 \%)$ (Lihat Tabel 1).

Tabel 1. Responden berdasarkan Jenis Kelamin, Status Pernikahan, Pendidikan, Status Kepegawaian, dan Ruang Perawatan di RSUD Kabupaten Mamuju

\begin{tabular}{|c|c|c|c|c|c|}
\hline Variabel Penelitian & $\mathbf{n}$ & $\%$ & Variabel Penelitian & $\mathbf{n}$ & $\%$ \\
\hline Jenis Kelamin & & & Status Pernikahan & & \\
\hline Perempuan & 85 & 91,4 & Belum Kawin & 42 & 45,2 \\
\hline \multirow[t]{3}{*}{ Laki-Laki } & 8 & 8,6 & Kawin & 50 & 53,8 \\
\hline & & & Janda/Duda & 1 & 1,1 \\
\hline & & & Pendidikan & & \\
\hline Ruang Perawatan & & & DIII Keperawatan & 59 & 63,4 \\
\hline Ruang VIP & 20 & 21,5 & S1 Keperawatan & 27 & 29,0 \\
\hline Ruang Perawatan Bedah & 19 & 20,4 & S1 Keperawatan + Ners & 7 & 7,5 \\
\hline $\begin{array}{l}\text { Ruang Penyakit Dalam } \\
\text { (Interna) }\end{array}$ & 18 & 19,4 & Status Kepegawaian & & \\
\hline Ruang Perawatan Anak & 18 & 19,4 & Sukarela & 23 & 24,7 \\
\hline \multirow[t]{3}{*}{ Ruang NICU } & 18 & 19,4 & Honor & 3 & 3,2 \\
\hline & & & Kontrak & 47 & 50,5 \\
\hline & & & PNS & 20 & 21,5 \\
\hline
\end{tabular}

Pendokumentasian berdasarkan Standar Asuhan Keperawatan

Pendokumentasian keperawatan

berdasarkan pengkajian keperawatan sebagian besar dalam kategori kurang lengkap yaitu 91 perawat $(97,8 \%)$, kategori kurang akurat yaitu 88 perawat $(94,6 \%)$, sedangkan kategori kurang relevan yaitu 87 perawat $(97,8 \%)$. Pendokumentasian keperawatan berdasarkan diagnosis keperawatan di RSUD Kabupaten Mamuju yang masuk dalam kategori kurang lengkap yaitu 40 perawat (43\%), kategori kurang akurat yaitu 45 perawat $(48,4 \%)$, kategori relevan yaitu 47 perawat $(50,5 \%)$. Pendokumentasian keperawatan berdasarkan perencanaan keperawatan di RSUD Kabupaten Mamuju yang masuk dalam kategori kurang lengkap yaitu 46 perawat $(49,5 \%)$, kategori kurang akurat yaitu 45 perawat $(48,4 \%)$, kategori relevan yaitu 44 perawat $(47,3 \%)$. Pendokumentasian keperawatan berdasarkan implementasi keperawatan di RSUD Kabupaten Mamuju yang masuk dalam kategori lengkap yaitu 49 perawat $(52,7 \%)$, kategori akurat yaitu 46 perawat $(49,5 \%)$, kategori relevan yaitu 47 perawat $\quad(50,5 \%)$. Pendokumentasian keperawatan berdasarkan evaluasi keperawatan di RSUD Kabupaten Mamuju yang masuk dalam kategori lengkap yaitu 59 perawat $(63,4 \%)$, kategori akurat yaitu 59 perawat $(63,4 \%)$, kategori relevan yaitu 63 perawat $(67,7 \%)$.

\section{PEMBAHASAN}

Pengkajian adalah pemikiran dasar dari proses keperawatan yang bertujuan untuk 
mengumpulkan informasi atau data tentang klien agar dapat mengidentifikasi masalahmasalah yang dialami klien, mental, sosial dan lingkungan. Dokumentasi keperawatan dalam beberapa rumah sakit ditemukan bahwa kemampuan perawat mendokumentasikan hasil asuhan keperawatan rata-rata kurang dari $60 \%$.

Tabel 2. Pendokumentasian Standar Asuhan Keperawatan di Ruang Rawat Inap RSUD Kabuapaten Mamuju

\begin{tabular}{|c|c|c|c|c|c|}
\hline Variabel Penelitian & $\mathbf{n}$ & $\%$ & Variabel Penelitian & n & $\%$ \\
\hline Pengkajian Keperawatan & & & Implementasi Keperawatan & & \\
\hline Kelengkapan & & & Kelengkapan & & \\
\hline Kurang lengkap & 91 & 97,8 & Kurang lengkap & 30 & 32,3 \\
\hline Cukup lengkap & 2 & 2,2 & Cukup lengkap & 14 & 15,1 \\
\hline Lengkap & 0 & 0 & Lengkap & 49 & 52,7 \\
\hline Keakuratan & & & Keakuratan & & \\
\hline Kurang akurat & 88 & 94,6 & Kurang akurat & 30 & 32,3 \\
\hline Cukup akurat & 4 & 4,3 & Cukup akurat & 17 & 18,3 \\
\hline Akurat & 1 & 1,1 & Akurat & 46 & 49,5 \\
\hline Relevansi & & & Relevansi & & \\
\hline Kurang Relevan & 87 & 93,5 & Kurang Relevan & 30 & 32,3 \\
\hline Cukup Relevan & 6 & 6,5 & Cukup Relevan & 16 & 17,2 \\
\hline Relevan & 0 & 0 & Relevan & 47 & 50,5 \\
\hline Diagnosa Keperawatan & & & Evaluasi Keperawatan & & \\
\hline Kelengkapan & & & Kelengkapan & & \\
\hline Kurang lengkap & 40 & 43 & Kurang lengkap & 13 & 14 \\
\hline Cukup lengkap & 16 & 17,2 & Cukup lengkap & 21 & 22,6 \\
\hline Lengkap & 37 & 39,8 & Lengkap & 59 & 63,4 \\
\hline Keakuratan & & & Keakuratan & & \\
\hline Kurang akurat & 45 & 48,4 & Kurang akurat & 20 & 21,5 \\
\hline Cukup akurat & 5 & 5,4 & Cukup akurat & 14 & 15,1 \\
\hline Akurat & 43 & 46,2 & Akurat & 59 & 63,4 \\
\hline Relevansi & & & Relevansi & & \\
\hline Kurang Relevan & 35 & 37,6 & Kurang Relevan & 19 & 20,4 \\
\hline Cukup Relevan & 11 & 11,8 & Cukup Relevan & 11 & 11,8 \\
\hline Relevan & 47 & 50,5 & Relevan & 63 & 67,7 \\
\hline \multicolumn{6}{|l|}{ Perencanaan Keperawatan } \\
\hline \multicolumn{6}{|l|}{ Kelengkapan } \\
\hline Kurang lengkap & 46 & 49,5 & & & \\
\hline Cukup lengkap & 18 & 19,4 & & & \\
\hline Lengkap & 29 & 31,2 & & & \\
\hline \multicolumn{6}{|l|}{ Keakuratan } \\
\hline Kurang akurat & 45 & 48,4 & & & \\
\hline Cukup akurat & 5 & 5,4 & & & \\
\hline Akurat & 43 & 46,2 & & & \\
\hline \multicolumn{6}{|l|}{ Relevansi } \\
\hline Kurang Relevan & 43 & 46,2 & & & \\
\hline Cukup Relevan & 6 & 6,5 & & & \\
\hline Relevan & 44 & 47,3 & & & \\
\hline
\end{tabular}

Kelengkapan dokumentasi keperawatan diprediksi karena beberapa faktor, antara lain karena kesibukan perawat, pengalaman kerja (lama kerja), kedisiplinan maupun tingkat pendidikan perawat ataupun persepsi perawat terhadap pentingnya penulisan dokumentasi. Hasil penelitian ini menunjukkan bahwa pendokumentasian keperawatan berdasarkan 
kelengkapan pengkajian keperawatan sebagaian besar dalam kategori kurang lengkap yaitu 91 perawat $(97,8 \%)$ disebabkan format pengkajian sangat ringkas dan sederhana. Hal ini sejalan dengan penelitian di RSUD Tugurejo Semarang dengan hasil penelitian $58,8 \%$ tidak lengkap dalam mengisi dokementasi asuhan keperawatan (Pratiwi PP, Suryani M, Sayono, 2015). Hasil penelitian ini juga didukung oleh penelitian di Rumah Sakit Dr. H. Marzoeki Mahdi Bogor yang menunjukkan bahwa kelengkapan pengisian lembar pengkajian di ruang rawat inap sebesar $1,45 \%$ yang artinya bahwa banyak lembar pengkajian keperawatan pasien jiwa yang tidak terisi lengkap.

Dokumentasi proses asuhan
keperawatan yang baik dan berkualitas haruslah akurat, lengkap dan sesuai standar. Apabila kegiatan keperawatan tidak didokumentasikan dengan akurat dan lengkap maka sulit untuk membuktikan bahwa tindakan keperawatan telah dilakukan dengan benar (Pancaningrum D, 2015). Hasil penelitian ini menunjukkan bahwa pendokumentasian keperawatan berdasarkan keakuratan pengkajian keperawatan di RSUD Kabupaten Mamuju sebagian besar dalam kategori kurang akurat yaitu 88 perawat $(94,6 \%)$ disebabkan kurangnya motivasi kerja dan pengalaman perawat . Hasil penelitian ini sejalan dengan penelitian di Ruang Rawat Inap Rumah Sakit Jiwa Provinsi Aceh. Hasil penelitian tersebut menunjukkan bahwa pada pelaksanaan proses pencatatan asuhan keperawatan di ruang rawat inap Rumah Sakit Jiwa Aceh ditemukan adanya ketidakakuratan terhadap data yang dicatat dalam berkas dokumentasi asuhan keperawatan dan ditemukan adanya pencacatan dokumentasi asuhan keperawatan yang tidak segera dibuat setelah tindakan keperawatan dilakukan. Beberapa faktor yang mempengaruhi perawat dalam proses pelaksanaan pencatatan asuhan keperawatan di ruang rawat inap Rumah Sakit Jiwa Aceh antara lain adalah form dokumentasi yang kurang sistematis, kurangnya pelatihan, belum optimalnya pengawasan, kurangnya motivasi, kurangnya pengetahuan dan kompetensi perawat, beban kerja yang tinggi, keterbatasan waktu, dan tidak adanya sistem pemberian reward dan punishment yang jelas serta sikap pimpinan yang kurang tegas dalam hal pelaksanaan pencatatan asuhan keperawatan (Azis A, 2011).

Pengkajian yang sistematis dalam keperawatan dibagi dalam empat tahap kegiatan, yang meliputi pengumpulan data, analisis data, sistematika data dan penentuan masalah. Adapula yang menambahkannya dengan kegiatan dokumentasi data (meskipun setiap langkah dari proses keperawatan harus selalu didokumentasikan juga). Hal-hal yang harus diperhatikan dalam pengkajian diantaranya adalah data yang dikumpulkan harus menyeluruh meliputi aspek bio-psikososial dan spiritual, menggunakan berbagai sumber yang ada relevansinya dengan masalah klien dan menggunakan cara-cara pengumpulan data yang sesuai dengan kebutuhan klien, dilakukan secara sistematis dan terus-menerus, dicatat dalam catatan keperawatan secara sistematis dan terus-menerus, dikelompokkan menurut kebutuhan bio-psiko-sosial dan spiritual dan dianalisis dengan dukungan pengetahuan yang relevan (Yeni, 2008). Hasil penelitian ini menunjukkan bahwa pendokumentasian keperawatan berdasarkan relevansi pengkajian keperawatan di RSUD Kabupaten Mamuju sebagaian besar dalam kategori kurang relevan yaitu 87 perawat $(97,8 \%)$. Hal ini tidak sejalan dengan kriteria hasil pengkajian standar praktik keperawatan PPNI dengan kriteria data yang dihasilkan akurat, terkini, dan relevan sesuai kebutuhan klien.

Diagnosis Keperawatan merupakan keputusan klinik tentang respon individu, keluarga dan masyarakat tentang masalah kesehatan aktual atau potensial, dimana berdasarkan pendidikan dan pengalamannya, perawat secara akuntabilitas dapat mengidentifikasi dan memberikan intervensi secara pasti untuk menjaga, menurunkan, membatasi, mencegah dan merubah status kesehatan klien (Yeni, 2008). Untuk dapat merumuskan diagnosa keperawatan dibutuhkan kemampuan analisis yang tinggi sehingga diperlukan sumber daya manusia yang capable dan mempunyai motivasi kuat untuk maju serta berpandangan maju (futuristic). Pada status pasien yang telah dikaji terlihat bahwa perawat hanya memilih saja diagnosa keperawatan yang telah disediakan di bagian samping format pengkajian. Hal ini memang lebih memudahkan perawat akan tetapi juga dapat menyebabkan perawat menjadi malas dan kurang inisiatif untuk menganalisa data lalu merumuskan diagnosa keperawatan sendiri apabila ditemukan data yang berbeda. Kondisi demikian juga menimbulkan kualitas pendokumentasian diagnosa keperawatan 
menjadi monoton (Hartati, Handoyo, Anis, 2010). Hasil penelitian ini menunjukkan bahwa pendokumentasian keperawatan berdasarkan kelengkapan diagnosis keperawatan di RSUD Kabupaten Mamuju yang masuk dalam kategori kurang lengkap yaitu 40 perawat (43\%). Hasil penelitian ini berbeda dengan penelitian yang dilakukan Hartati, dkk. 2010 dengan judul Analisis Kelengkapan Dokumentasi Proses Keperawatan Pasien Rawat Inap Di RSU PKU Muhammadiyah Gombong Jawa Tengah. Hasil penelitian tersebut menunjukkan bahwa pendokumentasian tahap diagnosa keperawatan mendapat skore $60 \%$ (kategori cukup), akan tetapi masih ada beberapa aspek yang belum memenuhi standar asuhan keperawatan. Seperti aspek penulisan diagnosa harus spesifik dan akurat hanya mendapat skore $55 \%$. Ini merupakan batas minimal sekali karena memang terlihat penyusunan diagnosa masih ada yang bersifat umum dan belum spesifik. Disamping itu pada perumusan diagmosa aktual masih ada beberapa yang tidak mencantumkan sign atau symptom yang menjadi persyaratan utama bahwa diagnosa itu dikatakan aktual.

Kelengkapan pengisian berkas rekam medis oleh tenaga kesehatan akan memudahkan tenaga kesehatan lain dalam memberikan tindakan atau terapi kepada pasien. Selain itu juga sebagai sumber data pada bagian rekam medis dalam pengolahan data yang kemudian akan menjadi informasi yang berguna bagi pihak manajemen dalam menentukan langkah-langkah strategis untuk pengembangan pelayanan kesehatan ${ }^{8}$. Hasil penelitian ini menunjukkan bahwa pendokumentasian keperawatan berdasarkan keakuratan diagnosis keperawatan di RSUD Kabupaten Mamuju terbanyak dalam kategori kurang akurat yaitu 45 perawat $(48,4 \%)$ sedangkan kategori akurat hanya 43 perawat $(46,2 \%)$. Hasil penelitian ini sejalan dengan penelitian Wariyanti, A.R., 2013 dengan judul Hubungan Antara Kelengkapan Informasi Medis dengan Keakuratan Kode Diagnosis Pada Dokumen Rekam Medis Rawat Inap Di Rumah Sakit Umum Daerah Kabupaten Karanganyar. Hasil penelitian tersebut menunjukkan bahwa tingkat keakuratan kode diagnosis pada dokumen rekam medis dengan kategori tidak akurat berjumlah $26(59,1 \%)$ sedangkan kategori akurat berjumlah 18 (40,9\%). Faktor yang menyebabkan ketidakakuratan kode diagnosis diantaranya adalah kesalahan dalam menuliskan kode.
Pada prakteknya, perawat sering mengalami kesulitan dalam melaksanakan asuhan keperawatan. Sering sekali perawat kesulitan dalam hal menetapkan diagnosa keperawatan yang tepat bagi pasien. Pada kasus yang lain, data dikumpulkan tanpa menyadari mengenai apa diagnosanya?. Perawat juga mengumpulkan data yang mempunyai relevansi yang rendah dengan diagnosa keperawatan tertentu. Penelitian menunjukkan bahwa rendahnya keakuratan dalam diagnosa keperawatan berkaitan dengan banyaknya jumlah data yang relevansinya rendah (Nurjannah I, 2012). Hasil penelitian ini menunjukkan bahwa pendokumentasian keperawatan berdasarkan relevansi diagnosis keperawatan di RSUD Kabupaten Mamuju terbanyak dalam kategori relevan yaitu 47 perawat $(50,5 \%)$. Hasil penelitian ini sejalan dengan metode pendokumentasian diagnosa keperawatan yang mengharapkan membuat diagnosa keperawatan dengan sistem pencatatan yang relevan. Adapun persyaratan dari diagnosa keperawatan ialah perumusan wajib jelas dan singkat dari respons klien terhadap situasi yang dihadapi, spesifik dan akurat, memberikan arahan pada askep, bisa dikerjakan oleh perawat dan mencerminkan keadaan kesehatan klien (Zulfikar, 2015).

Perencanaan merupakan tahap selanjutnya setelah pengkajian dan penentuan diagnosa keperawatan. Perencanaan juga merupakan petunjuk tertulis yang menggambarkan secara tepat mengenai rencana tindakan yang dilakukan terhadap pasien sesuai dengan tingkat kebutuhan berdasarkan diagnosa keperawatan yang muncul. Untuk itu rencana tindakan yang baik tentunya harus berdasarkan pada diagnosa keperawatan yang telah dirumuskan (Hartati, Handoyo, Anis, 2010). Tahap perencanaan merupakan suatu proses penyusunan berbagai intervensi keperawatan yang dibutuhkan untuk mencegah, menurunkan atau mengurangi masalah-masalah klien. Dalam menentukan tahap perencanaan bagi perawat diperlukan berbagai pengetahuan dan keterampilan diantaranya pengetahuan tentang kekuatan dan kelemahan klien, nilai dan kepercayaan klien, batasan praktek keperawatan, peran dari tenaga kesehatan lainnya, kemampuan dalam memecahkan masalah, mengambil keputusan, menulis tujuan serta memilih dan membuat strategi keperawatan yang aman dalam memenuhi tujuan, menulis instruksi keperawatan serta 
kemampuan dalam melaksanakan kerja sama dengan tingkat kesehatan lain. Hasil penelitian ini menunjukkan bahwa pendokumentasian keperawatan berdasarkan kelengkapan perencanaan keperawatan di RSUD Kabupaten Mamuju yang masuk dalam kategori kurang lengkap yaitu 46 perawat $(49,5 \%)$. Hal ini berbeda dengan hasil penelitian yang dilakukan Hartati, dkk. 2010 dengan judul Analisis Kelengkapan Dokumentasi Proses Keperawatan Pasien Rawat Inap Di RSU PKU Muhammadiyah Gombong Jawa Tengah. Hasil penelitian tersebut menunjukkan bahwa status pasien yang telah dikaji terlihat pendokumentasian tahap perencanaan mendapat skore 59\% (kategori cukup), akan tetapi masih ada beberapa aspek yang belum memenuhi standar asuhan keperawatan.

Rencana tindakan keperawatan dibuat berdasarkan kebutuhan klien. Pelaksanaan praktik keperawatan dilakukan sesuai dengan rencana yang telah disepakati bersama antara klien dan keluarganya. Pelaksanaan praktik keperawatan harus berpedoman pada standar profesi (Putra, A. 2010). Dalam memberikan pelayanan, perawat memberikan asuhan keperawatan yang terangkum dalam satu siklus yaitu proses keperawatan. Pelaksanaan asuhan keperawatan yang simultan tersebut akan mendatangkan implikasi terhadap tingkat kepuasan klien. Salah satu ciri profesionalisme adalah adanya cara kerja profesional setiap subyek yang ada di dalamnya dan diantaranya didukung dengan dokumentasi yang akurat, jelas, terpercaya dan sah secara hukum (Rimbun LR, 2012). Hasil penelitian ini menunjukkan bahwa pendokumentasian keperawatan berdasarkan keakuratan perencanaan keperawatan di RSUD Kabupaten Mamuju terbanyak dalam kategori kurang akurat yaitu 45 perawat $(48,4 \%)$. Menurut analisa peneliti hal ini diakibatkan karena terbatasnya tenaga keperawatan yang terampil dalam menyusun perencanaan. Hal ini sejalan dengan penelitian Angelica at.al (2006) dengan judul Building An Innovation Electronic Nursing Record Pilot Structure With Nursing Clinical Pathway yang menyatakan bahwa dalam proses keperawatan yang terdiri dari 5 tahapan dibutuhkan perawat dalam mengelola banyak data dan informasi sedangkan jumlah perawat yang ada tidak seimbang, hal ini membutuhkan keterampilan agar cakap/mampu dalam menyusun perencanaan dan melakukan proses yang efektif efisien dan benar. Dengan menggunakan tekhnologi komputer maka akan menghasilkan kualitas pelayanan yang baik, berpusat pada pasien dan perawatan kesehatan yang efisien. Selain itu dapat mempermudah pengambilan keputusan untuk melakukan tindakan keperawatan tahap demi tahap. Salah satu sistem yang disusun adalah dengan menyusun struktur pencatatan keperawatan dengan elektronik yang terintegrasi dengan standar keperawatan internasional untuk mendukung kecakapan dan keakuratan perencanaan keperawatan dalam clinical pathway process (Rimbun LR, 2012).

Menurut ANA (American Nurse Association) dalam Suyani, L. (2013) menyebutkan ada enam standar praktik untuk informasi keperawatan yaitu pengkajian, berfokus pada pasien yang meliputi identitas pasien, identifikasi hasil, hasil siklus teknologi informasi dari pasien dan data pasien dalam mendukung adanya perubahan dalam pembuatan keputusan, diagnosa, meliputi seluruh aktivitas yang berhubungan dengan identifikasi hasil yang menggambarkan hasil perawatan yang terukur, perencanaan, penggunaan teknologi yang digunakan untuk menambah dan merubah data yang relevan ke dalam perencanaan keperawatan, implementasi, merupakan pemberian tindakan yang nyata kepada pasien, evaluasi, digunakan untuk efisiensi dan efektifitas keputusan, perencanaan dan pelaksanaan untuk meningkatkan praktik keperawatan. Hasil penelitian ini menunjukkan bahwa pendokumentasian keperawatan berdasarkan relevansi perencanaan keperawatan di RSUD Kabupaten Mamuju terbanyak dalam kategori relevan yaitu 44 perawat $(47,3 \%)$ sedangkan kategori kurang relevan sebanyak 43 perawat $(46,2 \%)$. Hal ini sesuai dengan kategori dalam menentukan prioritas masalah, harus dibuat perencanaan keperawatan (care plan) tentang masalah aktual atau harus dibuat perencanaan keperawatan sesuai dengan kondisi klien (Widyamarta DE, 2014).

Dokumentasi yang lengkap harus menggunakan standar keperawatan yang digunakan sebagai penilaian kerja perawat dalam melaksanakan asuhan keperawatan mulai dari pengkajian, diagnosa keperawatan, intervensi dan implementasi keperawatan sampai evaluasi (Potter dan Perry, 2009). Implementasi tindakan keperawatan disesuaikan dengan rencana tindakan keperawatan. Sebelum melaksanakan tindakan yang sudah direncanakan, perawat perlu 
memvalidasi dengan singkat apakah rencana tindakan masih sesuai dan dibutuhkan klien sesuai dengan kondisinya saat ini. Perawat juga menilai diri sendiri, apakah mempunyai kemampuan interpersonal, intelektual, teknikel, sesuai dengan tindakan yang akan dilaksanakan (Nurjanah S, 2013). Hasil penelitian ini menunjukkan kinerja implementasi perawat di RSUD Kabupaten Mamuju dalam kategori lengkap $52,7 \%$.

Implementasi adalah pengelolaan dan perwujudan dari rencana keperawatan yang telah di susun pada tahap perencanaan. Ukuran intervensi keperawatan yang diberikan kepada klien terkait dengan dukungan, pengobatan, tindakan untuk memperbaiki kondisi, pendidikan untuk klien-keluarga, atau tindakan untuk mencegah masalah kesehatan yang muncul dikemudian hari. Untuk kesuksesan pelaksanaan implementasi keperawatan agar sesuai dengan rencana keperawatan, perawat harus mempunyai kemampuan kognitif (intelektual), kemampuan dalam hubungan interpersonal, dan keterampilan dalam melakukan tindakan. Proses pelaksanaan implementasi harus berpusat kepada kebutuhan klien, faktor-faktor lain yang mempengaruhi kebutuhan keperawatan.

Hasil penelitian ini sejalan dengan tulisan Lestari, C. E. dan Rosyidah (2011) yang menyatakan bahwa standar asuhan keperawatan harus terus ditinjau keakuratannya, sehingga tidak terjadi suatu kesalahan yang dapat merugikan pasien, selain itu perawat juga harus terus dibina untuk pencapaian kinerja yang profesional dan bertanggung jawab terhadap tugas-tugasnya. Pelatihan atau seminar dapat mengasah kemampuan para perawat untuk lebih baik. Hasil penelitian menunjukkan bahwa penyebab atau pun kendala perawat melaksanakan pengisian dokumen standar asuhan keperawatan adalah terbatasnya sumber daya manusia sehingga pekerjaan yang akan dilakukan begitu banyak dan kurangnya waktu untuk melakukan pengisian.

Perawat mengimplementasikan tindakan yang telah diidentifikasi dalam rencana asuhan keperawatan. Implementasi ini untuk mencapai tujuan yang telah ditetapkan dan partisipasi klien dalam tindakan keperawatan berpengaruh pada hasil yang diharapkan (PPNI, AIPNI dan AIPDiKI, 2012). Hasil penelitian ini menunjukkan bahwa pendokumentasian keperawatan berdasarkan relevansi implementasi keperawatan terbanyak dalam kategori relevan sebanyak 47 perawat $(50,5 \%)$.

Evaluasi adalah mengkaji respon pasien terhadap tindakan keperawatan yang telah dilakukan oleh perawat dengan mengacu pada standar atau kriteria hasil yang telah ditetapkan pada rumusan tujuan. Terlihat pada status pasien yang telah dikaji bahwa kriteria keherhasilan yang dapat digunakan sebagai dasar evaluasi ini tidak selalu dicantumkan sehingga evaluasi yang dilakukan kurang mengacu pada tujuan (Hartati, 2010). Hasil penelitian ini menunjukkan pendokumentasian keperawatan berdasarkan kelengkapan evaluasi asuhan keperawatan di RSUD Kabupaten Mamuju terbanyak dalam kategori lengkap $63,4 \%$.

Evaluasi merupakan proses yang berkelanjutan untuk menilai efek dari tindakan keperawatan kepada klien. Evaluasi dilakukan terus menerus pada respon klien terhadap tindakan keperawatan yang dilaksanakan (Kol, Jacobson dan Wieler, 2003). Evaluasi dibagi menjadi dua yaitu evaluasi proses atau formatif dilakukan setiap selesai melaksanakan tindakan, evaluasi hasil atau sumatif dilakukan dengan membandingkan respon klien pada tujuan khusus dan tujuan umum yang telah ditentukan (Nurjanah S, 2013). Hasil penelitian ini menunjukkan bahwa pendokumentasian keperawatan berdasarkan keakuratan evaluasi keperawatan di RSUD Kabupaten Mamuju terbanyak dalam kategori akurat $63,4 \%$.

Tahap evaluasi merupakan perbandingan yang sistematik dan terencana tentang kesehatan klien dengan tujuan yang telah ditetapkan, dilakukan berkesinambungan dengan melibatkan klien dan tenaga kesehatan lainnya. Evaluasi dalam keperawatan merupakan kegiatan dalam menilai tindakan keperawatan yang telah ditentukan, untuk mengetahui pemenuhan kebutuhan klien secara optimal dan mengukur hasil dari proses keperawatan. Menurut Craven dan Hirnle (2000) Evaluasi didefenisikan sebagai keputusan dari efektifitas asuhan keperawatan antara dasar tujuan keperawatan klien yang telah ditetapkan dengan respon prilaku klien yang tampil. Hasil penelitian ini menunjukkan bahwa pendokumentasian keperawatan berdasarkan relevansi evaluasi keperawatan di RSUD Kabupaten Mamuju terbanyak dalam kategori relevan $67,7 \%$. 


\section{KESIMPULAN DAN SARAN}

Pendokumentasian

keperawatan berdasarkan pengkajian keperawatan di RSUD Kabupaten Mamuju kategori kurang lengkap $97,8 \%$, diagnosis keperawatan masih ada kurang lengkap $(48,4 \%)$, perencanaan keperawatan masih ada kategori kurang lengkap $(49,5 \%)$, implementasi keperawatan kategori lengkap $52,7 \%$, dan berdasarkan evaluasi keperawatan masuk dalam kategori relevan $67,7 \%$.

Perlu diadakan pelatihan tentang asuhan keperawatan secara berkesinambungan sehingga perawat mampu meningkatkan pemahaman asuhan keperawatan dengan baik dan benar, bagi perawat yang mempunyai masa kerja masih baru maupun yang sudah lama. Perlu ada pengawasan dan pemberian reward dan punishment yang jelas serta sikap pimpinan yang tegas dalam hal pelaksanaan dan pencatatan asuhan keperawatan

\section{DAFTAR PUSTAKA}

Nursalam. (2011). Manajemen Keperawatan. Edisi 3. Salemba medika; 287-94.

Pratiwi PP, Suryani M, Sayono. (2015). Hubungan Tingkat Pendidikan dan Lama Kerja dengan Kelengkapan Pengisian Dokumentasi Pengkajian Asuhan Keperawatan di RSUD Tugurejo Semarang. Program Studi S1 Keperawatan STIKES Telogorejo. http://download.portalgaruda. org/article. php.

Pancaningrum D. (2015). Sistem Pendokumentasian Asuhan Keperawatan di Rumah Sakit. Pasca Sarjana Peminatan Kepemimpinan dan Manajemen Keperawatan Fakultas Ilmu Keperawatan Universitas Indonesia. http://pkko.fik. ui.ac.id/files/Sistem.

Azis A. (2011). Analisis Proses Pendokumentasian Asuhan Keperawatan di Ruang Rawat Inap Rumah Sakit Jiwa Provinsi Aceh. Program Studi S2 Ilmu Kesehatan Masyarakat Universitas Gadjah Mada. http://etd.repository. ugm.ac.id/index.php.

Yeni. (2008). Pengkajian Keperawatan. https://yenibeth.wordpress.com/2008/06/ 01/ diagnosis-keperawatan-4.

Hartati, Handoyo, Anis. (2010). Analisis kelengkapan dokumentasi proses keperawatan pasien rawat inap di RSU PKU Muhammadiyah Gombong Jawa Tengah. http://digilib. Stikesmuh gombong. ac. id/.

Wariyanti AS. (2014). Hubungan antara Kelengkapan Informasi Medis Dengan Keakuratan Kode Diagnosis pada Dokumen Rekam Medis Rawat Inap di Rumah Sakit Umum Daerah Kabupaten Karanganyar. Program Studi Kesehatan Masyarakat Fakultas Ilmu Kesehatan Universitas Muhammadiyah Surakarta. http://eprints. ums.ac.id/.

Nurjannah I. (2012). Diagnostic Reasoning Dalam Proses Keperawatan. Program Studi Ilmu Keperawatan Fakultas Kedokteran UGM Yogyakarta.

Zulfikar. (2015). Tahapan proses keperawatan. http://diagnosa-keperawatan.kumpulan askep.com/ tahapan- proses-keperawatan64170/.

Rimbun LR. (2012). Penerapan Dokumentasi Keperawatan Elektronik dalam Praktek Keperawatan Sebagai Aplikasi dari Teknologi Informasi Keperawatan. program magister keperawatan kekhususan manajemen dan kepemimpinan keperawatan. FIK UI. http://www.kompasiana.com/.

Widyamarta DE. (2014). Tahap Perencanaan di Dalam Diagnosa Keperawatan/ Planning Phase In The Nursing Diagnosis. Ponorogo: I think my life: (diakses 12 Nov 2015). http://ithinkeducation.blogspot.co.id/201 4/01/tahap-perencanaan-di-dalam.

Nurjanah S. (2013). Gambaran Kelengkapan Pendokumentasian Asuhan Keperawatan di RSUD Pandan Arang Boyolali. Fakultas Ilmu Kesehatan Universitas Muhammadiyah Surakarta. http://eprints. ums.ac.id/26001/.

Nurcholis M. (2010). Implementasi keperawatan. Makalah dokumentasi keperawatan. dhttps://www.academia. edu/8537857/Makalah.

PPNI, AIPNI dan AIPDiKI. (2012). Standar Kompetensi Perawat Indonesia, Jakarta.

Hartati. (2010). Analisis Kelengkapan Dokumentasi Proses Keperawatan Pasien Rawat Inap di RSU PKU Muhammadiyah Gombong Jawa Tengah. http://digilib. stikesmuhgombong. ac.id. 